\title{
INGUINAL HERNIOPLASTY USING EXTERNAL OBLIQUE APONEUROSIS VERSUS LICHTENSTEIN MESH HERNIOPLASTY- A COMPARATIVE STUDY
}

\author{
Mayanka Singh ${ }^{1}$, Osman Musa², Chandra Shekhar ${ }^{3}$
}

1 Junior Resident, Department of Surgery, Era's Lucknow Medical College and Hospital, Lucknow, Uttar Pradesh, India.

2 Professor, Department of Surgery, Era's Lucknow Medical College and Hospital, Lucknow, Uttar Pradesh, India.

${ }^{3}$ Associate Professor, Department of Surgery, Era's Lucknow Medical College and Hospital, Lucknow, Uttar Pradesh, India.

\begin{tabular}{l}
\hline ABSTRACT \\
BACKGROUND \\
Using synthetic prosthesis (mesh) during Lichtenstein mesh hernioplasty causes clinical problems, such as foreign body sensation \\
in the groin, discomfort, abdominal wall stiffness, and migration of the mesh from the primary site of implantation. Additionally, \\
procreation and sexual function are reportedly seriously affected after surgical hernia treatment with mesh. Using external oblique \\
aponeurosis for tissue-based groin hernia repair may reduce these complications.
\end{tabular}

\section{METHODS}

A total of 40 (50\%) patients were operated using Lichtenstein mesh repair technique. These patients were included in Group A. Remaining 40 (50\%) were operated using external oblique aponeurosis technique. These patients were included in Group B. This is a non-randomized control trial. Lichtenstein repair was done according to established technique as per standard protocols. 6" x 3 " polypropylene mesh was used. In external oblique aponeurosis method, a flap of external oblique aponeurosis was created and sutured to inguinal ligament at one border and to conjoint tendon on the other border to form the new posterior wall, anterior to transversalis fascia.

\section{RESULTS}

Statistically, there was no significant difference between the two groups with respect to mean age of patients, side involved, type of hernia, suture removal time, duration of hospital stay, and time taken for returning to work. Mean time taken for surgery was $17.1 \%$ shorter in group A as compared to group B. Statistically, there was no significant difference between the two groups with respect to different immediate post-operative complications ( $p>0.05$ ); though at all the follow-up intervals, proportion of those reporting pain was higher in Group A, this difference was not significant statistically ( $p>0.05)$. At six months, recurrence rate was $2.5 \%$ in Group A and $5 \%$ in Group B.

\section{CONCLUSIONS}

EOA offers a biocompatible option to mesh in view of no significant difference in immediate post-operative complications like infection. Also, tissue repair using EOA can be an effective alternative in sepsis and strangulated hernia cases where LMH is not done. In the present study, a high recurrence rate was an issue of concern, however, for other aspects, EOA was found to be either comparable or better than LMH.

HOW TO CITE THIS ARTICLE: Singh M, Musa O, Shekhar C. Inguinal hernioplasty using external oblique aponeurosis versus Lichtenstein mesh hernioplasty- a comparative study. J. Evolution Med. Dent. Sci. 2019;8(16):1324-1330, D0I: $10.14260 /$ jemds/2019/295

\section{BACKGROUND}

Inguinal hernia is the most common abdominal wall hernia and consequently inguinal hernia repair ranks among one of the most often performed surgical procedures.

Some of the common methods of choice for inguinal hernia repair include (Rehman et al., 2010) ${ }^{1}$

1. Lytle repair.

2. Bassini repair.

3. Shouldice repair.

4. Darn repair.

5. Lichtenstein repair (Mesh repair).

6. Stoppa's repair.

7. Laparoscopic extraperitoneal and intraperitoneal mesh hernioplasty.

8. External oblique aponeurosis (Desarda) repair.

'Financial or Other Competing Interest': None.

Submission 01-03-2019, Peer Review 08-04-2019,

Acceptance 15-04-2019, Published 22-04-2019.

Corresponding Author:

Dr. Chandra Shekhar,

\#1898 E-Block, Rajajipuram,

Lucknow, Uttar Pradesh, India.

E-mail: csr13582@gmail.com

DOI: $10.14260 /$ jemds $/ 2019 / 295$
During 1980s, modern herniologists like Lichtenstein in 1986 and Gilbert in 1987 had simply laid a swatch of mesh without sutures deep to or in front of fascia transversalis with good results.2,3,4 However, in the year 2001, Desarda presented a new method for inguinal hernia repair by using an undetached strip of external oblique aponeurosis that did not use a mesh.5,6

Contemporary literature reports Lichtenstein repair to be a tension free repair associated with negligible rates of recurrence. 7,8 It has become a standard method of treatment for inguinal hernia9. However, use of synthetic prostheses (mesh) during the Lichtenstein mesh hernioplasty can create new clinical problems, such as foreign body sensation in the groin, discomfort, and abdominal wall stiffness, which may affect the everyday functioning of the patient. ${ }^{10}$ Surgical-site infections, often with clinical symptoms delayed for many years, are more frequent after hernia treatment using mesh.11,12 Migration of the mesh from the primary site of implantation in the abdominal cavity is one of the most dangerous complications. ${ }^{13,14,15}$ Intense chronic inflammatory process typically associated with foreign body reactions around the mesh prosthesis may produce meshoma or plugoma tumours, the treatment of which becomes a new surgical challenge. ${ }^{16,17,18}$ Additionally, procreation and sexual 
functions are reportedly seriously affected after surgical hernia treatment with mesh. ${ }^{14,19}$

In view of these stated complications and postoperative dysfunction, the Desarda method using external oblique aponeurosis, which was presented in 2001, became a new surgical option for tissue-based groin hernia repair. However, the clinical evidence comparing it with the already established techniques like Lichtenstein mesh repair is scarce and is in building phase.

Hence, the present study was carried out to compare the efficacy of Lichtenstein Mesh Hernioplasty with External oblique aponeurosis to find out their feasibility, effectiveness and complications in our environment.

\section{METHODS}

\section{Place of Study}

Department of Surgery, Era's Lucknow Medical College, Lucknow.

\section{Type of Study}

Non-randomized control trial study.

\section{Study Population}

Patients of inguinal hernia attending the Surgery OPD and indoor wards of Era's Lucknow Medical College, Lucknow.

\section{Study Duration}

18 months, (January 2017 to June 2018)

\section{Ethical Considerations}

The study was approved by Institutional Ethics Committee, Era's Lucknow Medical College, Lucknow. Informed consent was obtained from all the participants.

\section{Method}

All the patients fulfilling the inclusion criteria and not falling in the domain of exclusion criteria were invited to participate in the study. Only those providing informed consent were included in the study. Details regarding age, side involved, and type of hernia (direct/indirect) were noted.

The patients were then included into one of the following two groups-

\section{Group A}

Patients operated using Lichtenstein technique.

\section{Group B}

Patients operated using external oblique aponeurosis.

All the patients received intravenous antibiotic (Cefoperazone) single pre- and post-operative dose as per protocol.

The patients were operated either under general or spinal anaesthesia according to patient's fitness status.

In Group A, Lichtenstein repair using 6"x3" polypropylene mesh was done according to established technique as per standard protocol and precautions.

In Group B, a flap of external oblique aponeurosis was created and sutured to inguinal ligament at one border and to conjoint tendon on the other border to form the new posterior wall, anterior to transversalis fascia.

\section{Sample Size}

Sample size estimation was based on the basis of recurrence rate of the two groups using the formula:

$$
\mathrm{n}=\frac{(\mathrm{Z} \alpha+\mathrm{Z} \beta)^{2}}{\{\ln (1-\mathrm{e})\} 2}+\frac{(1-\mathrm{p} 1)}{\mathrm{p} 1}+\frac{(1-\mathrm{p} 2)}{\mathrm{p} 2}
$$

Where, $\quad \mathrm{p}_{1}=0.02$

$\mathrm{p}_{2}=0.083$

Risk rate $\mathrm{e}=0.95$

Type I error $\alpha=2.5 \%$

Type II error $\beta=20 \%$ for detecting results with $80 \%$ power of study

Data loss $=10 \%$

The sample size came out to be:

$\mathrm{n}=40$ in each group

Patients were allotted to groups by Random Table Method.

\section{Inclusion Criteria}

All male patients undergoing elective inguinal hernia surgeries for either direct or indirect hernia.

\section{Exclusion Criteria}

- Patients aged below 18 years.

- Female patients.

- Bilateral or recurrent inguinal hernias.

- Patients in whom general anaesthesia and spinal anaesthesia are contraindicated and medically unfit for operation.

- $\quad$ Those affected with HIV, HCV, HBsAg, Diabetes mellitus.

\section{Statistics}

Data so obtained was fed into computer using Microsoft Excel 2013 software and subjected to statistical analysis. The values were represented in Number (\%) and Mean \pm SD. Variables were compared by using Student's t-test and Chi-square test $P$ value of $<0.05$ was taken as significant. The statistical analysis was done using SPSS (Statistical Package for Social Sciences) Version 21.0 statistical Analysis Software.

\section{RESULTS}

The present study was conducted with an aim to find out the efficacy of inguinal hernioplasty using external oblique aponeurosis as compared to Lichtenstein mesh hernioplasty. For this purpose, a non-randomized study was carried out in which a total of 80 male patients with inguinal hernia were enrolled and were allocated to one of the following two groups:

\begin{tabular}{|c|c|c|c|c|}
\hline $\begin{array}{r}\text { Sl. } \\
\text { No. }\end{array}$ & Group & Description & No. of Cases & $\%$ \\
\hline 1. & A & $\begin{array}{c}\text { Patients of inguinal } \\
\text { hernia who were } \\
\text { operated using } \\
\text { Lichtenstein technique }\end{array}$ & 40 & 50 \\
\hline 2. & B & $\begin{array}{c}\text { Patients of inguinal } \\
\text { hernia who were } \\
\text { operated using external } \\
\text { oblique aponeurosis }\end{array}$ & 40 & 50 \\
\hline \multicolumn{4}{|c|}{ Table 1. Group Wise Distribution of Cases } \\
\hline
\end{tabular}


A total of 40 (50\%) patients were operated using Lichtenstein mesh repair technique and comprised the Group A of study while remaining $40(50 \%)$ were operated using external oblique aponeurosis technique and comprised the Group B of study.

\begin{tabular}{|c|c|c|c|c|c|}
\hline \multirow{2}{*}{$\begin{array}{l}\text { Sl. } \\
\text { No. }\end{array}$} & \multirow{2}{*}{ Age Group } & \multicolumn{2}{|c|}{ Group A $(n=40)$} & \multicolumn{2}{|c|}{ Group B $(n=40)$} \\
\hline & & No. & $\%$ & No. & $\%$ \\
\hline 1. & $\leq 20$ Years & 1 & 2.5 & 3 & 7.5 \\
\hline 2. & 21-30 Years & 5 & 12.5 & 8 & 20 \\
\hline 3. & 31-40 Years & 11 & 27.5 & 11 & 27.5 \\
\hline 4. & 41-50 Years & 7 & 17.5 & 8 & 20 \\
\hline 5. & 51-60 Years & 11 & 27.5 & 7 & 17.5 \\
\hline 6. & $61-70$ Years & 4 & 10 & 3 & 7.5 \\
\hline 7. & $>70$ Years & 1 & 2.5 & 0 & 0 \\
\hline \multicolumn{2}{|c|}{$\begin{array}{c}\text { Mean Age } \pm \text { SD } \\
\text { (Range) }\end{array}$} & \multicolumn{2}{|c|}{$45.00 \pm 14.33(18-80)$} & \multicolumn{2}{|c|}{$39.98 \pm 13.49(18-68)$} \\
\hline \multicolumn{6}{|c|}{ Table 2. Age-Wise Distribution of Cases in The Two Groups } \\
\hline \multicolumn{6}{|c|}{$' t^{\prime}=1.615 ; p=0.110$} \\
\hline
\end{tabular}

Age of patients ranged from 18 to 80 years. Majority of patients in both the groups were aged between 31 and 60 years. Mean age of patients in Group A was $45.00 \pm 14.33$ years whereas mean age of patients in Group B was 39.98 \pm 13.49 years. Though mean age of patients in Group A was higher as compared to that of patients in Group B yet the difference between two groups was not significant statistically $(\mathrm{p}=0.110)$.

\begin{tabular}{|c|c|c|c|c|c|c|c|}
\hline \multirow[t]{2}{*}{$\begin{array}{l}\text { Sl. } \\
\text { No. }\end{array}$} & \multirow[t]{2}{*}{ Characteristic } & \multicolumn{2}{|c|}{$\begin{array}{l}\text { Lichtenstein } \\
\text { Method } \\
\text { (n=40) } \\
\text { Group A }\end{array}$} & \multicolumn{2}{|c|}{$\begin{array}{c}\text { External } \\
\text { Oblique } \\
\text { Aponeurosis } \\
\text { Method } \\
(n=40) \\
\text { Group B }\end{array}$} & \multicolumn{2}{|c|}{$\begin{array}{l}\text { Statistical } \\
\text { Significance }\end{array}$} \\
\hline & & No. & $\%$ & No. & $\%$ & $\chi^{2}$ & 'p' \\
\hline \multirow{3}{*}{1.} & Side & & & & & & \\
\hline & Left & 6 & 15.0 & 10 & 25.0 & \multirow{2}{*}{1.250} & \multirow{2}{*}{0.264} \\
\hline & Right & 34 & 85.0 & 30 & 75.0 & & \\
\hline \multirow{3}{*}{2.} & Type & & & & & & \\
\hline & Direct & 13 & 32.5 & 6 & 15.0 & \multirow{2}{*}{3.382} & \multirow{2}{*}{0.066} \\
\hline & Indirect & 27 & 67.5 & 34 & 85.0 & & \\
\hline
\end{tabular}

Right side was more commonly involved than left side in both the groups. In Group A, 34 (85\%) patients and in Group B, $30(75 \%)$ patients showed involvement of right side. Statistically, there was no significant difference between two groups with respect to side involved ( $\mathrm{p}=0.264)$.

In Group A, 13 (32.5\%) had direct and 27 (67.5\%) had indirect hernia whereas in Group B, 6 (15\%) had direct and 34 $(85 \%)$ had indirect hernia. Though proportion of those having direct hernia was higher in Group A as compared to that in Group B yet this difference was not significant statistically $(p=0.066)$.

\begin{tabular}{|c|c|c|c|c|c|}
\hline Sl. & Time Taken for & \multicolumn{1}{|c|}{ Group A (n=40) } & Group B (n=40) \\
\cline { 3 - 6 } No. & Surgery (Minutes) & No. & $\%$ & No. & $\%$ \\
\hline 1. & $\leq 40$ minutes & 40 & 100 & 13 & 32.5 \\
\hline 2. & $>40$ minutes & 0 & 0 & 27 & 62.5 \\
\hline Mean Time Taken \pm SD & $34.83 \pm 2.12$ & $42.02 \pm 1.72$ \\
(Range) in Minutes & \multicolumn{3}{|c|}{$(30-40)$} & $(40-45)$ \\
\hline Table 4. Comparison of Time Taken for Surgery Between the \\
Two Groups \\
\hline \multicolumn{6}{|c|}{$' t$ ' $=16.633 ; \mathrm{p}<0.001$} \\
\hline
\end{tabular}

Time taken for surgery ranged from 30 to 40 minutes in Group A and from 40 to 45 minutes in Group B. In Group A, the time taken for surgery was within 40 minutes in all the patients whereas in Group B, in a total of 13 (32.5\%) patients surgery was done within 40 minutes while in 27 (62.5\%) cases, surgery was done after 40 minutes. Mean time taken for surgery was $34.83 \pm 2.12$ minutes in Group A as compared to $42.02 \pm 1.72$ minutes in Group B. Statistically, this difference was significant $(\mathrm{p}<0.001)$.

There were no intraoperative complications in either of two groups.

\begin{tabular}{|c|c|c|c|c|}
\hline $\begin{array}{c}\text { Sl. } \\
\text { No. }\end{array}$ & Characteristic & $\begin{array}{c}\text { Group } \\
\text { A } \\
(\mathrm{n}=40)\end{array}$ & $\begin{array}{c}\text { Group } \\
\mathbf{B} \\
(\mathrm{n}=40)\end{array}$ & $\begin{array}{c}\text { Statistical } \\
\text { Significance }\end{array}$ \\
\hline 1. & $\begin{array}{c}\text { Seroma } \\
\text { formation }\end{array}$ & $\begin{array}{c}3 \\
(7.5 \%)\end{array}$ & $\begin{array}{c}3 \\
(7.5 \%)\end{array}$ & $\chi^{2}=0 ; \mathrm{p}=1$ \\
\hline 2. & Infection & $\begin{array}{c}1 \\
(2.5 \%)\end{array}$ & 0 & $\begin{array}{c}\chi^{2}=1.013 ; \\
\mathrm{p}=0.314\end{array}$ \\
\hline 3. & Hematoma & 0 & $\begin{array}{c}1 \\
(2.5 \%)\end{array}$ & $\begin{array}{c}\chi^{2}=1.013 ; \\
\mathrm{p}=0.314\end{array}$ \\
\hline 4. & Scrotal oedema & 0 & $\begin{array}{c}1 \\
(2.5 \%)\end{array}$ & $\begin{array}{c}\chi^{2}=1.013 ; \\
\mathrm{p}=0.314\end{array}$ \\
\hline 5. & $\begin{array}{c}\text { Other } \\
\text { complications }\end{array}$ & - & - & - \\
\hline \multicolumn{4}{|c|}{ Table 5. Comparison of Immediate Post-Operative } \\
Complications in The Two Study Groups
\end{tabular}

In Group A, seroma formation and infection were noted as the complications in $3(7.5 \%)$ and 1 (2.5\%) patient respectively whereas in Group B, seroma formation, hematoma and scrotal oedema were seen in 3 (7.5\%), 1 (2.5\%) and $1(2.5 \%)$ patient respectively. Statistically, there was no significant difference between two groups with respect to different immediate post-operative complications ( $p>0.05)$.

\begin{tabular}{|c|c|c|c|c|}
\hline & Characteristic & $\begin{array}{l}\text { Grol } \\
(n=\end{array}$ & $\begin{array}{l}\text { Grol } \\
(n=\end{array}$ & \begin{tabular}{|c|} 
Statistical \\
Significance
\end{tabular} \\
\hline 1. & $\begin{array}{r}\text { Mean } \\
\text { sutur } \\
(\mathrm{R}\end{array}$ & $\begin{array}{c}7.90 \pm 1.89 \\
(2-11)\end{array}$ & $\begin{array}{r}7.63 \\
(2\end{array}$ & $\begin{array}{l}' \mathrm{t} \text { ' } \\
\mathrm{p}=\end{array}$ \\
\hline 2. & $\begin{array}{l}\text { Mea } \\
\text { hosf } \\
\text { (Ra }\end{array}$ & $\begin{array}{r}5.90 \pm \\
(5-1\end{array}$ & $\begin{array}{r}6.13 \\
(5\end{array}$ & $\begin{array}{l}' t '= \\
p=\end{array}$ \\
\hline 3. & $\begin{array}{r}\text { Mean ti } \\
\text { return } \\
(\text { Ran }\end{array}$ & $\begin{array}{r}11.10 \\
(10\end{array}$ & $\begin{array}{r}11.2 \\
(10\end{array}$ & 't'= \\
\hline \multicolumn{5}{|c|}{$\begin{array}{c}\text { Table 6. Comparison of The Time Taken for Suture } \\
\text { Removal, Duration of Hospital Stay, and Time Taken for } \\
\text { Return to Work in The Two Study Groups }\end{array}$} \\
\hline
\end{tabular}

Time taken for suture removal ranged from 2 to 12 days. Mean time taken for suture removal was $7.90 \pm 1.89$ days in Group A and 7.63 \pm 1.94 days in Group B. Statistically, there was no significant difference between two groups with respect to mean time taken for suture removal $(\mathrm{p}=0.523)$.

Duration of hospital stay ranged from 5 to 14 days in both the groups. Mean duration of hospital stay was $5.90 \pm 2.45$ days in Group A and 6.13 \pm 2.45 days in Group B. Though mean duration of hospital stay was longer in Group B as compared to that in Group A yet this difference was not significant statistically $(\mathrm{p}=0.701)$.

Time taken for return to work ranged from 10 to 22 days in both the groups, mean time taken for return to work was 
$11.10 \pm 3.20$ days in Group A and 11.20 \pm 3.29 days in Group B. Statistically, the difference between two groups was not significant $(\mathrm{p}=0.891)$.

\begin{tabular}{|c|c|c|c|c|}
\hline Sl. No. & Time interval & $\begin{array}{c}\text { Group A } \\
(\mathbf{n = 4 0 )}\end{array}$ & $\begin{array}{c}\text { Group B } \\
(\mathbf{n = 4 0 )}\end{array}$ & $\begin{array}{c}\text { Statistical } \\
\text { Significance }\end{array}$ \\
\hline 1. & One month & $4(10 \%)$ & $2(5 \%)$ & $\begin{array}{c}\chi^{2}=0.721 ; \\
\mathrm{p}=0.396\end{array}$ \\
\hline 2. & Two months & $7(17.5 \%)$ & $2(5 \%)$ & $\begin{array}{r}\chi^{2}=3.130 ; \\
\mathrm{p}=0.077\end{array}$ \\
\hline 3. & Six months & $7(17.5 \%)$ & $2(5 \%)$ & $\begin{array}{r}\chi^{2}=3.130 ; \\
\mathrm{p}=0.077\end{array}$ \\
\hline
\end{tabular}

Table 7. Comparison of Post-Operative Pain in The Two Study Groups at Different Follow Up Intervals

On one month, two months and six months' follow-up, a total of $4(10 \%), 7$ (17.5\%) and 7 (17.5\%) patients of Group A and $2(5 \%), 2(5 \%)$ and $2(5 \%)$ patients of Group B complained of pain. Though at all the follow-up intervals, proportion of those reporting pain was higher in Group A as compared to that in Group B, yet this difference was not significant statistically ( $p>0.05)$.

No other complication was noted in any patient at any follow up.

\begin{tabular}{|c|c|c|c|}
\hline Sl. No. & Recurrence & $\begin{array}{c}\text { Group A } \\
(\mathbf{n = 4 0 )}\end{array}$ & $\begin{array}{c}\text { Group B } \\
(\mathbf{n = 4 0 )}\end{array}$ \\
\hline 1. & No & $39(97.5 \%)$ & $38(95.0 \%)$ \\
\hline 2. & Yes & $1(2.5 \%)$ & $2(5.0 \%)$ \\
\hline Table 8. Comparison of Recurrence Between the Two \\
Groups
\end{tabular}

At six months, recurrence rate was $2.5 \%$ in Group A and $5 \%$ in Group B. Though the recurrence rate was higher in Group B as compared to that in Group A yet this difference was not significant statistically $(\mathrm{p}=0.556)$.

Master chart of patients was prepared as they were operated according to the group they belonged, and then statistical analysis was applied.

\section{Operative Images}

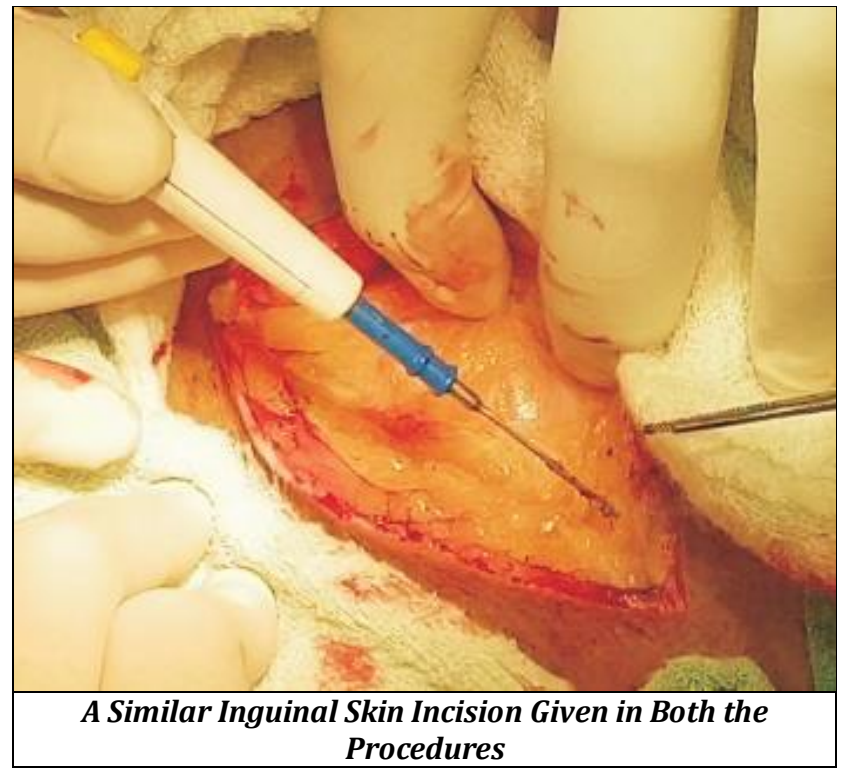

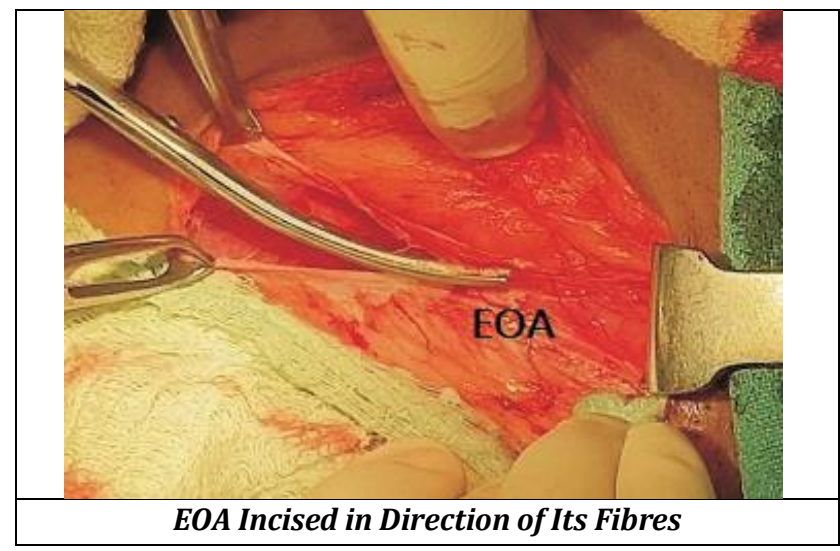
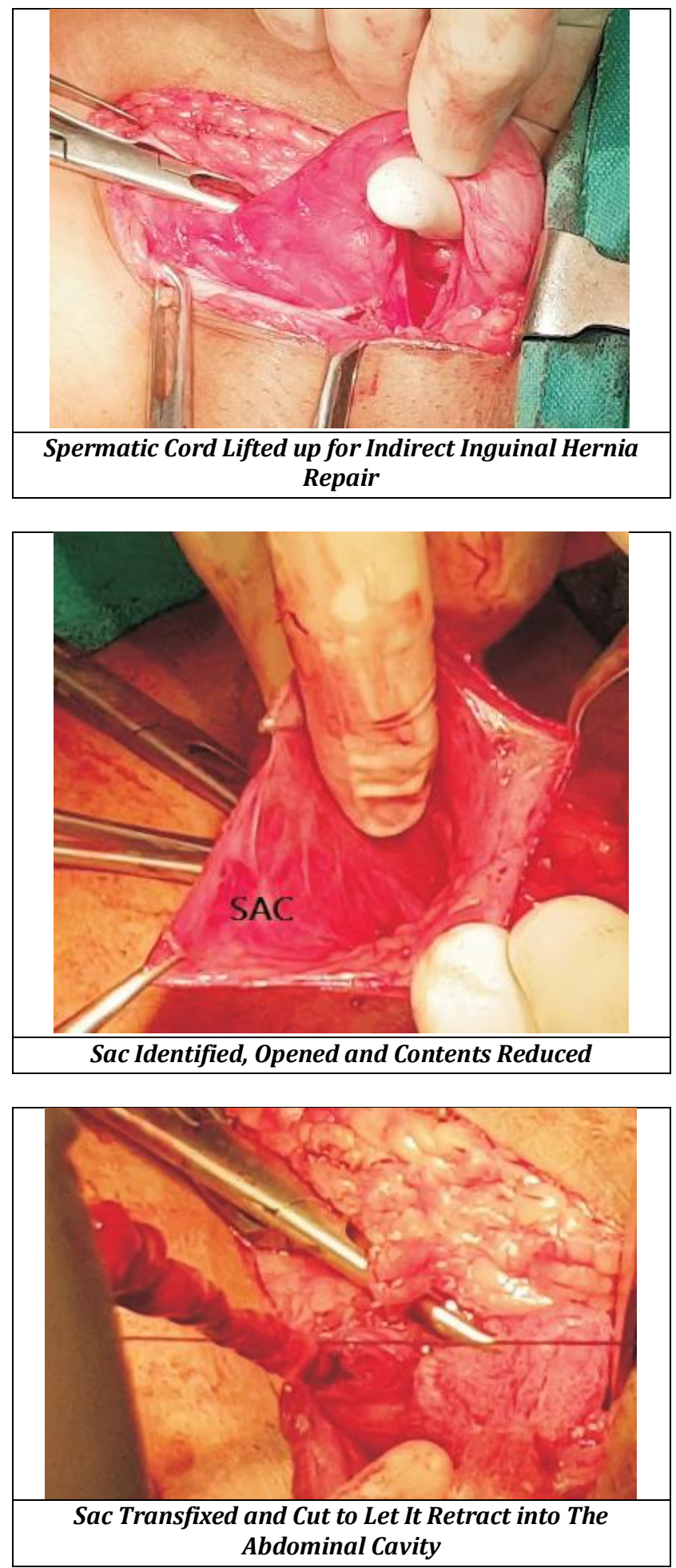

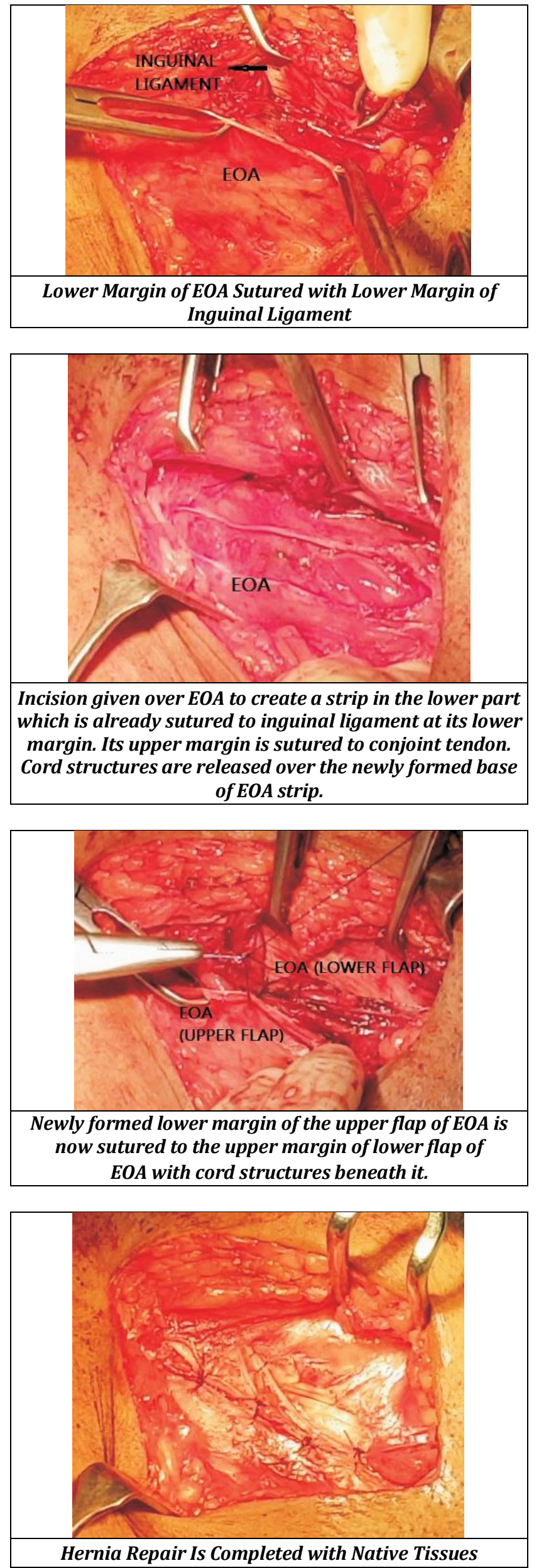

Incision for repair using external oblique aponeurosis was same as that of Lichtenstein technique.

Interrupted sutures with Prolene 2-0 were used for both the procedures.

Intraoperative complications were looked upon and time taken for the procedure was noted.

Immediate post-operative complications, viz. seroma formation, infection, hematoma, scrotal oedema, etc. were noted.

Time taken for suture removal, duration of hospital stay and time taken for return to work was noted.

Patients were followed up to 6 months after surgery at one month, two months and six months interval.

Postoperative pain and recurrence were observed using a visual analogue scale. Pain scores $\geq 5$ indicated a clinically significant pain.

\section{DISCUSSION}

Lichtenstein mesh hernioplasty is the most common procedure for management of inguinal hernia. No doubt this method of hernia repair is simple and safe. But the mesh prosthesis has its drawbacks. Mesh works as a mechanical barrier. It does not give mobile and physiologically dynamic posterior wall. ${ }^{20}$ The synthetic prostheses can create new clinical problems, such as foreign body sensation in the groin, discomfort and abdominal wall stiffness, which may affect the everyday functioning of the patient. ${ }^{21}$ Moreover, complications like mesh migration, surgical site infection, development of meshoma or plugoma tumours ${ }^{18}$ are frequent complications encountered during the long-term. One of the most common reason for mesh-related complications in Lichtenstein's mesh repair is the synthetic nature of the mesh. In this direction, external oblique aponeurosis repair is one such technique which was introduced in the year $2001^{5}$ and since then being used clinically in different parts of world. The key characteristic of this technique is that it causes no tension on suture lines as seen in tension repairs and there is no foreign body used like mesh repairs.

With this background, the present study was carried out as a non-randomized trial with an aim to find out whether inguinal hernioplasty using external oblique aponeurosis is as effective as Lichtenstein mesh hernioplasty.

A total of 80 male patients with inguinal hernia were enrolled and were included in one of the two groups - Group A- a total of $40(50 \%)$ patients who were managed using Lichtenstein mesh hernioplasty (LMH); Group B- remaining 40 $(50 \%)$ who were managed using external oblique aponeurosis (EOA) technique.

In present study, age of patients ranged from 18 to 80 years. Mean age of patients in Lichtenstein and external oblique aponeurosis groups was $45.00 \pm 14.33$ and $39.98 \pm 13.49$ years respectively.

The present study included all male patients. Inguinal hernia is relatively rare in females. Most of the studies reviewed by us follow an all-male design. Considering the low prevalence but a possible gender associated confounding effect, we preferred to follow an all-male study design only.

The present study included only unilateral hernia cases and right side was more commonly involved in both the groups. A total of 34 (85\%) of Lichtenstein and 30 (75\%) of External oblique aponeurosis group patients had involvement of right side. Inguinal hernias are characteristically more 
common on the right than on the left side, however, the proportion varies in different studies. ${ }^{22}$

In present study, though we included both direct as well as indirect inguinal hernia cases yet in both the groups majority of cases had indirect hernia. Overall, more than $75 \%$ cases had indirect hernia. Epidemiologically too, indirect hernias are reported to be twice as common as direct hernia. 22

In present study, we did not find any significant difference between two groups with respect to age, side involved and type of hernia, thus satisfying the criteria of statistically matched groups and ensuring that these variables do not have a confounding effect on the outcome.

In present study, mean duration of surgery was significantly shorter in Lichtenstein group $(34.83 \pm 2.12 \mathrm{~min})$ as compared to that in External oblique aponeurosis group $(42.02 \pm 1.72 \mathrm{~min})$. Thus, the mean time taken for surgery was $17.1 \%$ shorter in LMH group as compared to EOA group. Although, a longer mean operative time in EOA group in present study could be attributable to preparation of a flap of external oblique aponeurosis and its suturing. As such the difference in operative time depends on mainly on the surgical skill of the surgeon. In present study, the surgical procedures were performed by a senior consultant who had performed more than $1000 \mathrm{LMH}$ repairs and is highly skilled in performing those procedures, whereas EOA was relatively newer procedure. We expect that with increasing adaptation the operative time will decrease significantly.

In present study, during immediate post-operative interval, seroma formation and infection were seen in 3 and 1 case respectively in Lichtenstein group whereas in External oblique aponeurosis group, seroma formation, hematoma and scrotal oedema were noted in 3,1 and 1 case respectively. Statistically, there was no significant difference between two groups with respect to immediate-post-operative complications. Both these techniques do not have much immediate post-operative complications.

In present study, at one-, two- and six-months interval, proportion of those complaining of clinically significant pain was higher in Lichtenstein group as compared to that in External oblique aponeurosis group. At six months, 17.5\% patients of Lichtenstein group and 2.5\% of External oblique aponeurosis group reported of pain. However, the difference between two groups was not significant statistically.

After six months, recurrence was noted in only $1(2.5 \%)$ case in Lichtenstein group as compared to $2(5.0 \%)$ in External oblique aponeurosis group. However, the difference between two groups was not significant statistically. The finding might be incidental only.

\section{CONCLUSIONS}

One must understand that EOA offers a biocompatible option to mesh in view of no significant difference in immediate postoperative complications like infection. Also, tissue repair using EOA can be an effective alternative in sepsis and strangulated hernia cases where LMH is not done. In the present study, a high recurrence rate was an issue of concern; however, for other aspects, EOA was found to be either comparable or better than LMH. In view of the cheaper cost of the procedure, strangulated hernia, sepsis cases, it can be recommended as a viable alternative that can promise better clinical outcome. Further studies on a larger sample size with longer duration of follow-up are recommended.

\section{REFERENCES}

[1] Rehman QU, Shah TA Latif U. Inguinal hernia: Lichtenstein and Darn Repair: a comparative study. Prof Med J 2010;17(1):50-4.

[2] Legutko J, Peach R, Solecki R, et al. The history of treatment of groin hernia. Folia Med Cracov 2008;49(12):57-74.

[3] Yaghoobi NA, Yaghoobi NA Jr, Seied FJ, et al. Outcomes of the Rives Stoppa technique in incisional hernia repair: ten years of experience. Hernia 2007;11(1):259.

[4] Deysine M. Recurrent inguinal herniorrhaphy: a centripetal approach utilizing a pre-formed polypropylene plug. Hernia 2008;12(3):271-5.

[5] Desarda MP. New method of inguinal hernia repair: a new solution. ANZ J Surg 2001;71(4):241-4.

[6] Desarda MP. Inguinal herniorrhaphy with an undetached strip of external oblique aponeurosis: a new approach used in 400 patients. Eur J Surg 2001;167(6):443-8.

[7] Kaynak B, Celik F, Guner A, et al. Moloney darn repair versus lichtenstein mesh hernioplasty for open inguinal hernia repair. Surgery Today 2007;37(11):958-60.

[8] Friis E. Tension free herniotomy using the Lichtenstein's method. Results of five years' experience. Ugeskr-Laeger 2000;162(11):1556-9.

[9] Gourgiotis S, Germanos S, Stratopoulos C, et al. Lichtenstein tension free repair of inguinal hernia. Chirugia (Bucu) 2006;101(5):509-12.

[10] D'Amore L, Gossetti F, Vermeil V, et al. Long-term discomfort after plug and patch hernioplasty. Hernia 2008;12(4):445-6.

[11] Genc V, Ensari C, Ergul Z, et al. A very late-onset deep infection after prosthetic inguinal hernia repair. Chirurgia (Bucur) 2010;105(4):555-7.

[12] Scott NW, McCormack K, Graham P, et al. Open mesh versus non-mesh for repair of femoral and inguinal hernia. Cochrane Database Syst Rev 2002;(4):CD002197.

[13] Jeans S, Williams GL, Stephenson BM. Migration after open mesh plug inguinal hernioplasty: a review of the literature. Am Surg 2007;73(3):207-9.

[14] Ott V, Groebli Y, Schneider R. Late intestinal fistula formation after incisional hernia using intraperitoneal mesh. Hernia 2005;9(1):103-4.

[15] Benedetti M, Albertario S, Niebel T, et al. Intestinal perforation as a long-term complication of plug and mesh inguinal hernioplasty: case report. Hernia 2005;9(1):93-5.

[16] McRoy LL. Plugoma and the prolene hernia system. J Am Coll Surg 2011;212(3):425.

[17] Miller JP, Acar F, Kaimaktchiev VB, et al. Pathology of ilioinguinal neuropathy produced by mesh entrapment: case report and literature review. Hernia 2008;12(2):213-6.

[18] Fawole AS, Chaparala RPC, Ambrose NS. Fate of the inguinal hernia following removal of infected prosthetic mesh. Hernia 2006;10(1):58-61.

[19] Uzzo RG, Lemack GE, Morrissey KP, et al. The effects of mesh bioprosthesis on the spermatic cord structures: a 
preliminary report in a canine model. J Urol 1999;161(4):1344-9.

[20] Vrijland WW, Van Den Tol MP, Luijendijk RW, et al. Randomized clinical trial of non-mesh versus mesh repair of primary inguinal hernia. $\mathrm{Br} \mathrm{J}$ Surg 2002;89(3):293-7.
[21] D'Amore L, Gossetti F, Vermeil V, et al. Long-term discomfort after plug and patch hernioplasty. Hernia 2008;12(4):445-6.

[22] Mclntosh A, Hutchinson A, Roberts A, et al. Evidencebased, management of groin hernia in primary care - a systematic review. Fam Pract 2000;17(5):442-7. 